\title{
Thermal Management in Automotive Applications
}




\title{
Other SAE books of interest:
}

\author{
Engine Emissions Measurement Handbook \\ By Hiroshi Nakamura and Masayuki Adachi
}

(Product Code: JPF-HOR-002)

\author{
Fuel/Engine Interactions \\ By Gautam Kalghatgi \\ (Product Code: R-409)
}

\section{Introduction to Internal Combustion Engines, Fourth Edition \\ By Richard Stone \\ (Product Code: R-391)}

\author{
For more information or to order a book, contact: \\ SAE INTERNATIONAL \\ 400 Commonwealth Drive \\ Warrendale, PA 15096 \\ Phone: +1.877 .606 .7323 (U.S. and Canada only) \\ or +1.724 .776 .4970 (outside U.S. and Canada) \\ Fax: +1.724.776.0790 \\ Email: CustomerService@sae.org \\ Website: books.sae.org
}




\section{Thermal Management in Automotive Applications By T. Yomi Obidi}

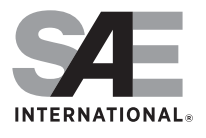

Warrendale, Pennsylvania, USA 


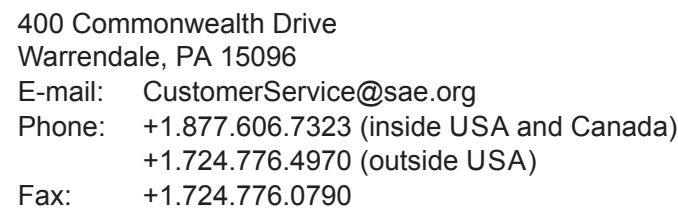

Copyright $@ 2015$ SAE International. All rights reserved.

No part of this publication may be reproduced, stored in a retrieval system, distributed, or transmitted, in any form or by any means without the prior written permission of SAE International. For permission and licensing requests, contact SAE Permissions, 400 Commonwealth Drive, Warrendale, PA 15096-0001 USA; e-mail: copyright@sae.org; phone: 724-772-4028; fax: 724-7729765.

\section{Library of Congress Catalog Number 2015934427 SAE Order Number PT-167 http://dx.doi.org/10.4271/pt-167}

Information contained in this work has been obtained by SAE International from sources believed to be reliable. However, neither SAE International nor its authors guarantee the accuracy or completeness of any information published herein and neither SAE International nor its authors shall be responsible for any errors, omissions, or damages arising out of use of this information. This work is published with the understanding that SAE International and its authors are supplying information, but are not attempting to render engineering or other professional services. If such services are required, the assistance of an appropriate professional should be sought.

\section{ISBN-Print 978-0-7680-8174-9 \\ ISBN-PDF 978-0-7680-8184-8 \\ ISBN-epub 978-0-7680-8186-2 \\ ISBN-prc 978-0-7680-8185-5}

To purchase bulk quantities, please contact

SAE Customer Service

e-mail: CustomerService@sae.org

phone: +1.877.606.7323 (inside USA and Canada)

+1.724 .776 .4970 (outside USA)

fax: +1.724 .776 .0790$

Visit the SAE Bookstore at

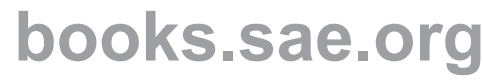




\section{Table of Contents}

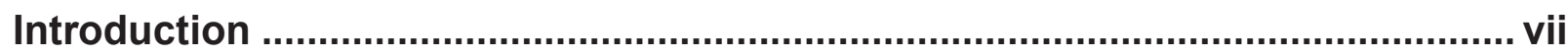

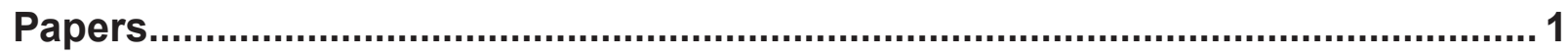

Thermal Management Concepts for Higher-Efficiency Heavy Vehicles

(1999-01-2240) 1

Engine Thermal Management with Electric Cooling Pump (2000-01-0965)..................9

Coolant Flow Control Strategies for Automotive Thermal Management Systems (2002-01-0713)

Smart Thermostat and Coolant Pump Control for Engine Thermal Management Systems (2003-01-0272)

Thermal Management on Small Gasoline Engines (2011-01-0314)

Cold Start Thermal Management with Electrically Heated Catalyst:

A Way to Lower Fuel Consumption (2013-24-0158).

Heat Management by Means of Thermal Barriers of Ceramic Fibers in

Automotive Components and Systems (931657).....

Underhood Thermal Management by Controlling Air Flow (951013)....

CFD Approach on Underhood Thermal Management of Passenger Cars and Trucks (2003-01-3577) 87

Nanofluids for Vehicle Thermal Management (2001-01-1706) 99 